Journal of Finance Research

\title{
Overview of the Relationship between Internal Control and Corporate Governance
}

\section{Xucui Li*}

Shandong Women's University, Jinan, Shandong, 250300, China

\begin{tabular}{ll}
\hline ARTICLE INFO & ABSTRACT \\
\cline { 2 - 2 } $\begin{array}{l}\text { Article history } \\
\text { Received: } 15 \text { May } 2020\end{array}$ & $\begin{array}{l}\text { As the global economic crisis deepens, people have a clearer understand- } \\
\text { ing of risks. Since internal control and corporate governance can better } \\
\text { control risks in the development of a company, how to properly handle } \\
\text { the relationship between internal control and corporate governance has }\end{array}$ \\
Revised: 22 May 2020 & $\begin{array}{l}\text { become the focus of research. There are mainly three views on the rela- } \\
\text { tionship between the two among scholars' researches including environ- } \\
\text { Accepted: } 9 \text { October } 2020\end{array}$ \\
mublished Online: 16 October 2020 & $\begin{array}{l}\text { of a company, asic theory and chimerism theory. In the normal operation } \\
\text { related, people are more inclined to the point of view of chimerism, } \\
\text { claiming that the two affect each other and they are inseparable. }\end{array}$ \\
\hline Keywords: &
\end{tabular}

Review

Mutual influence

\section{Introduction}

$\mathrm{S}$ ince Jenson and Meckling created the principal-agent theory, due to the "agent cost" that would result in a decline in corporate value, a corporate governance mechanism is expected to be created to reduce agency costs. Meanwhile, from the perspective of management, the ultimate goal of corporate governance and internal control is to realize corporate strategic goals ${ }^{[1]}$. Therefore, it is particularly important to correctly handle the relationship between internal control and corporate governance. At present, the relationship between the two is mainly demonstrated as environmental theory, chimerism theory and basic theory. Among them, the environment theory believes that, as the environmental element of internal control, corporate governance must be efficient in order to make the effectiveness of internal control better. Corporate governance is an institutional environment, while internal control is an internal management and monitoring system under the corporate governance system. At the same time, corporate governance affects the quality of internal control ${ }^{[2]}$. However, the chimerism theory advocates that internal control and corporate governance are mutually contained and influenced, underlining the endogenous nature of the two. It believes that internal control and corporate governance as two elements within the same system can influence each other and have an inherent structure. In addition, the basic theory believes that the effective operation of corporate governance is inseparable from the basic role of internal control ${ }^{[3]}$. Similarly, the study of internal control is also inseparable from the corporate governance environment.

\footnotetext{
*Corresponding Author:

Xucui Li(1985.12-),

Female; Han nationality; Master; Lecturer;

School of Accounting, Shandong Women's University;

Research direction: accounting, internal control;

E-mail: lixucuihere@163.com.
} 
To achieve the goals of internal control, corporate governance and internal control must have a good connection and an interactive combination ${ }^{[4]}$. Although many scholars have studied the relationship between internal control and corporate governance, and have drawn corresponding research conclusions, it spreads a thousand flowers bloom. There are many different opinions and they have not been unified. Therefore, this article first analyzes the concepts of internal control and corporate governance, and then summarizes and reviews existing views to further study the relationship between internal control and corporate governance to promote the company's development more healthily and effectively.

\section{Concept Definition}

\subsection{The Concept of Internal Control}

Internal control is a series of restraint, planning and evaluation measures implemented by the company. These measures are used to ensure the authenticity of the disclosed information and to ensure the company's operating effect and profit. With the development of internal control, its content, focus, methods and technical means have been gradually improved. At present, internal control has entered the stage of overall risk management framework. Many scholars put forward the overall framework of enterprise risk management on the basis of the overall framework of internal control. They believe that the risk management of an enterprise should be jointly participated by the board of directors, managers and employees. It covers the entire process from corporate strategy formulation to the execution of various departments and employees.

\subsection{The Concept of Corporate Governance}

Corporate governance in a broad sense not only revolves around the protection of shareholders' interests, but also includes the relationship between the company and other stakeholders, ensuring the company's scientific decision-making, and safeguarding the company's interests. The narrow sense of corporate governance is the corporate governance structure, which clearly divides the rights, obligations and responsibilities between the general meeting of shareholders, the board of directors, the board of supervisors and the managers. The characteristics of corporate governance are divided into internal governance features and external governance features. The characteristics of internal governance include the characteristics shown by internal regulatory agencies such as shareholding structure, the board of directors, the board of supervisors, management, and audit committee. And the characteristics of external governance refer to the supervision and management of external stakeholders related to the company.

\section{The Competition of Ideas}

Corporate governance and internal control are homologous, and the basis for their generation is principal-agent. However, corporate governance is based on solving the agency problem between owners and managers, and internal control is trying to solve the agency problem of agents at different levels. It is an extension of corporate governance contracts within the enterprise. The relationship between the two has been a hotly debated topic in academia.

\subsection{Environmental Theory: Corporate Gover- nance as an Environmental Element of Internal Control}

With the improvement of the legal system of internal control, internal control has expanded from serving the initial audit to serving the entire corporate governance. Relevant scholars have also focused their attention on the study of internal control and corporate governance. The environmental theory can be elaborated from the following two aspects.

\subsubsection{The Impact of the Macro Level of Corporate Governance on Internal Control}

Foreign scholars Udi and Rani pointed out SOX-404 and SOX-302 in 2009, pointing out that corporate governance efficiency is positively correlated with the effectiveness of internal control, and the improvement of corporate governance efficiency can affect the effectiveness of internal control. Therefore, good corporate governance can determine whether internal control is effective or not. In addition, corporate governance is a prerequisite for internal control, and it has a direct relationship with the operating effect and quality of internal control. Therefore, corporate governance can improve the quality of internal control of companies ${ }^{[5]}$. Focusing on the development of corporate governance and the improvement of structure can also promote the development of internal control. At the same time, it is not enough to overcome the limitations of the internal control system by relying solely on the improvement of the system itself, but also on the perfect fit between internal control and corporate governance on the basis of homology. Therefore, an effective way to improve internal control is to establish and improve the corporate governance.

\subsubsection{The Impact of Micro-Level Corporate Gov- ernance on Internal Control}

The internal and external characteristics of corporate gov- 
ernance have an important impact on the internal control of the company. For example, due to their independence, independent directors can help to exercise their supervisory functions, thereby improving the effectiveness of internal control. The concentration of equity will affect the rights of small and medium investors to a certain extent. In addition, elements of corporate governance such as corporate governance structure, board characteristics, and manager compensation also have an impact on internal control.

Many domestic scholars have also conducted a systematic study on the impact of corporate governance characteristics on internal control. Among them, the characteristics of the board of directors, equity structure (Zhao Jianfeng, 2013), the allocation of senior management rights (Liu Qiliang and Luo Le, etc., 2013), the audit committee and the CEO (Teng Weiru, 2017), etc. all have an impact on the effectiveness of internal control. The specific impact is shown in the following aspects: $\mathrm{Li}$ Jianhong pointed out in the article "A Research on Correlation between Corporate Governance Characteristics and Disclosure of Internal Control Defects" that the independence of the audit committee and the shareholding ratio of members of the supervisory board are significantly negatively related to internal control defects ${ }^{[6]}$. Even after the internal control defects are exposed, corporate governance has a significant impact on the repair of internal control defects. However, from the perspective of corporate governance, the relationship between the nature of the company's property rights and internal control is mutually influential, but the effect will vary among companies with different property rights ${ }^{[7]}$.

\subsection{Basic Theory: Internal Control as the Basis for Corporate Governance}

British scholars believe that internal control is an integral part of corporate governance. The Cadbury report first included internal control in corporate governance in 1992 and believed that effective internal control can enhance the effectiveness of corporate governance. Especially after Provision 404 of the SOX Act was put forward, stakeholders pointed out that the establishment and disclosure of internal control of the company will have an important impact on corporate governance. In 2011, Ye Chengang pointed out in the article "A Research on Internal Control Mechanism from the Perspective of Corporate Governance" that "internal control is the cost of specializing branches and the execution mechanism for achieving corporate governance objectives. The operation and results of corporate internal control are subject to corporate governance. At the same time, the management of the company must abide by the internal control system, and on the basis of legal compliance, establish and improve the internal control innovation mechanism according to the company's distinctive features ${ }^{[8]}$.

\subsection{Chimerism Theory: Internal Control and Corporate Governance Containing Each Other}

Goh discovered that corporate governance and internal control are mutually restrictive and influential through the disclosure of internal control information in 2007. In 2008, Stephen pointed out that internal control has a good role in promoting corporate governance. At the same time, domestic scholars believe that internal control and corporate governance are mutually integrated but not completely included. They are both different but connected. They complement each other, affect each other. They are inseparable, and are an organic and unified whole. However, to overcome the limitations of the internal control system, in addition to improving the internal control, it is also necessary to build good corporate governance so that the two can jointly promote the company's sustainable development. Moreover, an effective corporate governance mechanism can ensure the consistency of control objectives at different levels. In addition, the effectiveness of internal control is positively related to the company's governance efficiency, and the most fundamental purpose of both is to control the risks of the enterprise. In terms of the connection between the two, internal governance in corporate governance is included in internal control and is the top-level design of internal control, while management control in internal control is an extension and concretization of the strategic level of corporate governance ${ }^{[9]}$. A high level of corporate governance can improve the quality of internal control, and a high-quality internal control can also improve the level of corporate governance, and the impact of internal control quality on corporate governance is greater than the impact of corporate governance on internal control quality ${ }^{[10]}$.

\section{Conclusion}

To summarize, the relationship between internal control and corporate governance in academia has not yet been finalized. Internal control and corporate governance are the necessary conditions for the healthy operation of an enterprise, both of which are used to control the risks of the enterprise. The relationship between the two ultimately comes from the complexity of the company's business activities and governance structure. This paper advocates an extension based on the chimerism theory and believes that corporate governance lays the foundation for the effective 
implementation of internal control. At the same time, the good operation of internal control can also ensure the improvement of corporate governance. If analyzed from a broad perspective, the corporate governance system permeates the internal control thinking, which fully reflects the basic requirements of the company's internal control. Therefore, corporate governance and internal control are inseparable. From the perspective of enterprise management, corporate governance covers internal control, which can be understood as the scope of corporate governance. Therefore, to correctly handle the relationship between internal control and corporate governance is critical to the healthy development of an enterprise.

\section{References}

[1] Ye Chengang, Qiu Li, Zhang Lijuan. Corporate Governance Structure, Internal Control Quality and Corporate Financial Performance [J]. Auditing Research, 2016(02): 104-112.

[2] Tan Liyan. The Impact of Corporate Governance Characteristics on the Quality of Internal Control $[\mathrm{J}]$.Communication of Finance and Accounting, 2019(05): 52-55.

[3] Yang Xiongsheng. A New Perspective of Internal Control Theory Research [J]. Accounting Research, 2005, (07 :) 49-54.

[4] Yang Youhong, Hu Yan. On the Connection between Corporate Governance and Internal Control [J]. Accounting Research, 2004(10): 14-18.

[5] Zhu Caijie, Liu Changcui. Research on the Relevance of Corporate Governance and Internal Control Defect Repair-from the empirical data of state-owned listed companies from 2010 to 2014 [J]. Auditing Research, 2017(04): 97-105.

[6] Li Jianhong. Research on the Correlation between Corporate Governance Characteristics and Disclosure of Internal Control Defects [J]. Communication of Finance and Accounting, 2016(06): 78-81.

[7] Bai Yaxin. Property Right Nature, Internal Control and Enterprise Performance [J]. Huabei Finance, 2019(04): 12-19.

[8] Ye Chengang. A Research on Internal Control Mechanism from the Perspective of Corporate Governance [J]. Enterprise Economy, 2011(03): 5-9.

[9] Li Wei'an, Dai Wentao. The relationship Framework of Corporate Governance, Internal Control and Risk Management_ — based on the perspective of strategic management $[\mathrm{J}]$. Audit \& Economy Research, 2013(04): 3-12.

[10] Wu Lijun, Bu Hua. Corporate Governance, Internal Control and the Quality of Corporate Social Responsibility on Information Disclosure [J]. Communication of Finance and Accounting, 2019(12): 82-86.

[11] Stephen M.Corporate Governance Quality and Internal Control Reporting under Sox Section 302[J]. Proquest,Umi Dissertation Publishing,2008:23-34.

[12] Zhao jianfeng. "motivation selection" of internal control subject under different ownership structure [J]. Friends of accounting, 2013(09) :40-43.

[13] Liu qiliang, luo le. Executive centralization, internal control and accounting information quality [J]. Nankai management review, 2013(01):15-23.

[14] Teng weiru. Research on the relationship between corporate governance and internal control quality [D] Harbin: Harbin university of commerce, 2017. 